\title{
Autopsy of a Patient with Cushing's Syndrome Who Was Revealed to Have Pulmonary Tumorlets Producing Ectopic $\mathrm{ACTH}$
}

\author{
ATsushi OGO, TOMOAKi ETO, SHINSUKe HIRAMATSU, AKIMASA WATANABE, YOSHIYUKi SAKAI, \\ HIDEYUKI YOSHIZUMI, NORIKO UESUGI* AND OSAMU NAKAJIMA*
}

Department of Metabolism and Endocrinology, Clinical Research Institute, National Hospital Organization Kyushu Medical Center, 1-8-1 Jigyohama, Chuo-ku, Fukuoka City, 810-8563 Japan

*Department of Pathology, National Hospital Organization Kyushu Medical Center, 1-8-1 Jigyohama, Chuo-ku, Fukuoka City, 8108563 Japan

\begin{abstract}
The patient, a 78-year-old female with a 10-year history of type 2 diabetes mellitus, was admitted to our department for evaluation of leg edema and general fatigue. Biochemical investigations revealed hypokalemia and elevated serum cortisol and plasma ACTH levels, with a loss of diurnal rhythm and failure of suppression at high doses $(8 \mathrm{mg})$ of dexamethasone. No pituitary tumor or parasellar tumor was detected by contrast-enhanced computed tomography (CT) or magnetic resonance image scan of the pituitary. High resolution CT of the lung and bronchoscopic examination revealed no abnormalities. Abdominal and pelvic CT indicated bilateral, slightly diffuse, adrenal gland hyperplasia only. These findings led to a diagnosis of ACTH-dependent hypercortisolism from an undefined source. Ten days after admission the patient had a fever and was diagnosed with disseminated intravascular coagulation. Despite intensive treatment about 1 month after admission the patient died from progressive multiple organ failure. At autopsy, a histological examination of the periphery of the right middle lobe of the lung revealed the presence of tumorlets. Immunohistochemical staining of the tumorlets revealed scattered cells containing ACTH and many cells containing chromogranin A that were positive for Grimelius staining. In addition, multiple microabscesses were present throughout most tissues of the body. The ectopic hormonal production observed in the present case suggests that pulmonary tumorlets should thus be considered in the differential diagnosis of Cushing's syndrome, and medical treatment to inhibit steroidogenesis should be started immediately to reduce the risk of complications from hypercortisolism.
\end{abstract}

Key words: Pulmonary tumorlets, Ectopic ACTH syndrome, Autopsy, Diabetes mellitus

(Endocrine Journal 54: 863-870, 2007)

ECTOPIC hormone production is defined as tumorproduced hormone that is not normally produced by the tissue from which the tumor originates, and most of the tumors have proven to be malignant [1]. Wajchenberg et al. reported that $10-15 \%$ of cases of Cushing's syndrome are caused by ectopic adrenocorticotropic hormone (ACTH)-producing tumors. Of these tumors,

Received: July 19, 2007

Accepted: August 3, 2007

Correspondence to: Atsushi OGO, M.D., Ph.D., Department of Metabolism and Endocrinology, National Hospital Organization, Kyushu Medical Center, 1-8-1 Jigyohama, Chuo-ku, Fukuoka City, 810-8563 Japan
$35-49 \%$ were reported to be carcinoid tumors. Of the lung carcinoid tumors, $2 \%$ were reported to be ectopic ACTH-producing tumors [2]. In Japan, the ectopic ACTH-producing tumor has been observed in $3.6 \%$ of Cushing's syndrome cases and the frequency of the tumors causing ectopic ACTH syndrome was as follows, lung cancer, 49\%; carcinoid, $15.7 \%$, malignant thymic tumor, $9.8 \%$; pancreas cancer, $5.9 \%$; thyroid medullary cancer, 5.9\%; and pheochromocytoma, $2 \%[3,4]$. In recent years, an increasing number of pulmonary tumorlets have been reported as a result of the development of more sophisticated radiological imaging techniques. However, ectopic hormone production with clinical significance by pulmonary tumorlets is 
very rare. Although pulmonary tumorlets are still not well understood, the accumulated findings suggest that the concept of the pulmonary tumorlet as a tumor-like lesion or neuroendocrine cell hyperplasia needs to be reconsidered $[5,6]$. Histologically, distinguishing pulmonary tumorlets from a carcinoid tumor is difficult, since there are no definite histological criteria [7]. We herein report a case of pulmonary tumorlets producing ectopic ACTH which was revealed at autopsy in a patient with Cushing's syndrome.

\section{Case Report}

History and examination (Fig. 1)

A 78-year-old female with a 10-year history of type 2 diabetes mellitus was admitted to our department for evaluation of leg edema and general fatigue. However, she did not display a cushingoid appearance, such as moon face, hirsutism, acne, buffalo hump or abdominal striae. At this time (Table 1), her glycemic control was poor. Her fasting glucose level was $172 \mathrm{mg} / \mathrm{dl}$ and hemoglobin A1c was $8.5 \%$. The patient was treated for diabetes mellitus with 16 units/day of intermediateacting insulin. A biochemical and endocrinological investigation revealed hypokalemia $(1.8 \mathrm{mEq} / \mathrm{L})$ and elevated serum cortisol and plasma ACTH levels (The ACTH- IRMA kit Mitsubishi: Mitsubishi Kagaku Iatron, Inc. Tokyo, Japan) of $55.0 \mu \mathrm{g} / \mathrm{dl}$ and $329 \mathrm{pg} / \mathrm{ml}$ respectively, with loss of diurnal rhythm (Table 2). Urinary 17-OHCS, 17-KS and free cortisol excretion were also elevated to $15.2 \mathrm{mg} /$ day, $11.6 \mathrm{mg} /$ day and $1.45 \mathrm{mg} /$ day, respectively. Six months before this admission, she had undergone laminoplasty of the cervical spine at our hospital. At this time, her electrolytes

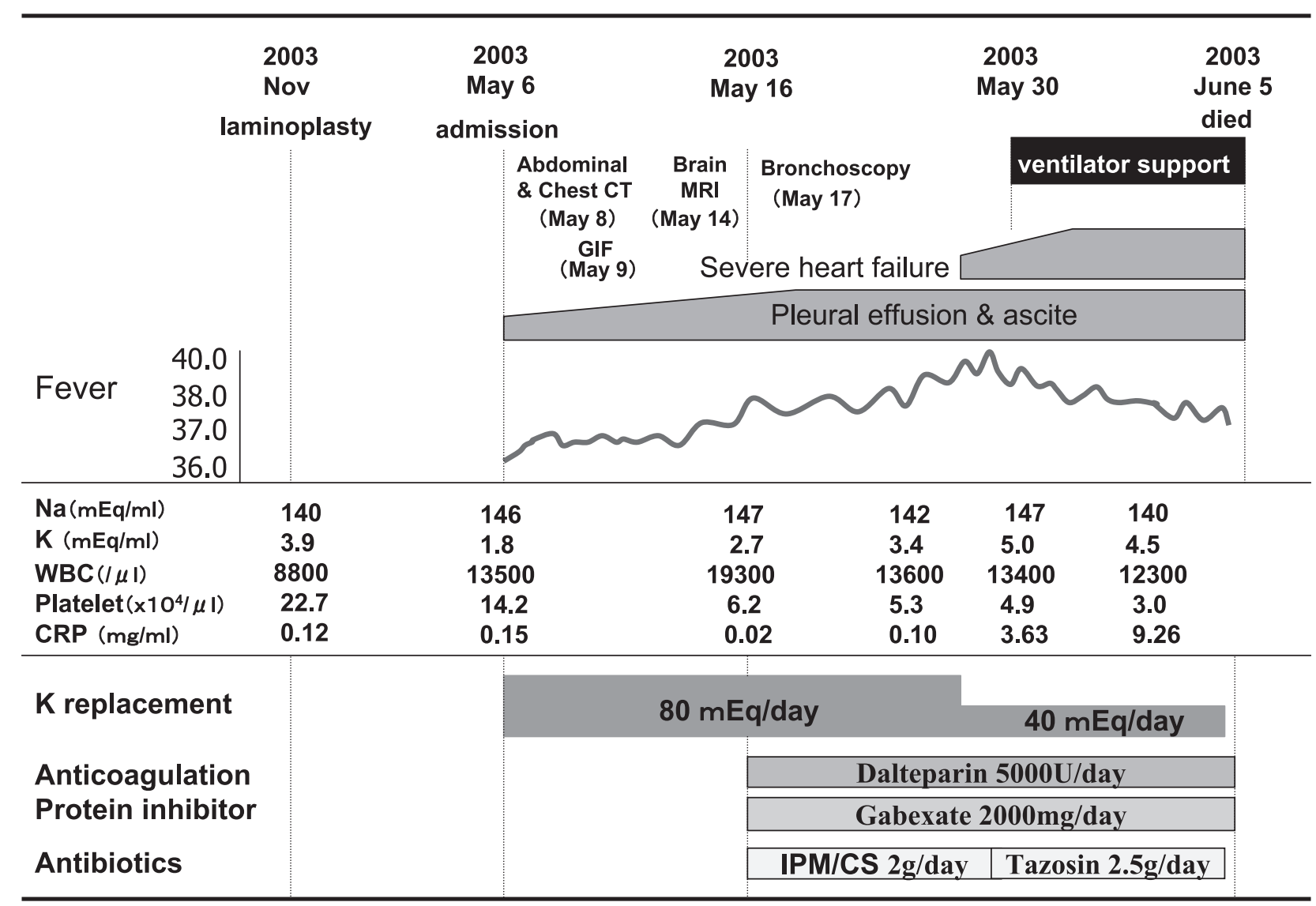

Fig. 1. Clinical course 
Table 1. Laboratory data on admission

\begin{tabular}{|c|c|}
\hline \multicolumn{2}{|l|}{ Urinalysis } \\
\hline Protein & $(+)$ \\
\hline Glucose & $(+)$ \\
\hline Occult blood & $(-)$ \\
\hline Ketone & $(-)$ \\
\hline \multicolumn{2}{|l|}{$\mathrm{CBC}$} \\
\hline WBC & $13500 / \mu 1$ \\
\hline $\mathrm{Neu}$ & $91.9 \%$ \\
\hline Eos & $0.1 \%$ \\
\hline Baso & $0.2 \%$ \\
\hline Mono & $2.6 \%$ \\
\hline Lympho & $5.2 \%$ \\
\hline $\mathrm{RBC}$ & $372 \times 10^{6} / \mu 1$ \\
\hline $\mathrm{Hb}$ & $11.4 \mathrm{~g} / \mathrm{dl}$ \\
\hline $\mathrm{Ht}$ & $33.6 \%$ \\
\hline Plt & $14.2 \times 10^{4} / \mu \mathrm{l}$ \\
\hline \multicolumn{2}{|l|}{ Blood chemistry } \\
\hline $\mathrm{TP}$ & $4.7 \mathrm{~g} / \mathrm{dl}$ \\
\hline Alb & $2.7 \mathrm{~g} / \mathrm{dl}$ \\
\hline T-Bil & $2.0 \mathrm{mg} / \mathrm{dl}$ \\
\hline $\mathrm{AST}$ & 37 IU/1 \\
\hline ALT & $46 \mathrm{IU} / 1$ \\
\hline $\mathrm{LDH}$ & $494 \mathrm{IU} / 1$ \\
\hline ALP & $333 \mathrm{IU} / 1$ \\
\hline$\gamma$-GTP & $48 \mathrm{IU} / 1$ \\
\hline AMY & $127 \mathrm{IU} / 1$ \\
\hline $\mathrm{CPK}$ & $69 \mathrm{IU} / 1$ \\
\hline BUN & $12 \mathrm{mg} / \mathrm{dl}$ \\
\hline Cre & $0.6 \mathrm{mg} / \mathrm{dl}$ \\
\hline TG & $107 \mathrm{mg} / \mathrm{dl}$ \\
\hline T-Chol & $156 \mathrm{mg} / \mathrm{dl}$ \\
\hline $\mathrm{Na}$ & $146 \mathrm{mEq} / \mathrm{l}$ \\
\hline K & $1.8 \mathrm{mEq} / 1$ \\
\hline $\mathrm{CI}$ & $86 \mathrm{mEq} / 1$ \\
\hline CRP & $0.15 \mathrm{mg} / \mathrm{dl}$ \\
\hline Glucose & $172 \mathrm{mg} / \mathrm{dl}$ \\
\hline $\mathrm{HbA} 1 \mathrm{c}$ & $8.5 \%$ \\
\hline \multicolumn{2}{|c|}{ Endocrinological data } \\
\hline ACTH & $329 \mathrm{pg} / \mathrm{ml}$ \\
\hline GH & $0.20 \mathrm{ng} / \mathrm{ml}$ \\
\hline LH & $0.10 \mathrm{mIU} / \mathrm{ml}$ \\
\hline FSH & $0.20 \mathrm{mIU} / \mathrm{ml}$ \\
\hline PRL & $13.9 \mathrm{ng} / \mathrm{ml}$ \\
\hline TSH & $0.032 \mu \mathrm{IU} / \mathrm{ml}$ \\
\hline FT4 & $1.39 \mathrm{ng} / \mathrm{ml}$ \\
\hline Cortisol & $55.0 \mu \mathrm{g} / \mathrm{dl}$ \\
\hline DHEA-S & $3190 \mu \mathrm{g} / \mathrm{dl}$ \\
\hline 17-OHCS & $15.2 \mathrm{mg} /$ day \\
\hline $17-\mathrm{KS}$ & $11.6 \mathrm{mg} /$ day \\
\hline PRA & $0.3 \mathrm{ng} / \mathrm{ml} / \mathrm{hr}$ \\
\hline Aldosterone & $42 \mathrm{pg} / \mathrm{ml}$ \\
\hline CA: AD & $79 \mathrm{pg} / \mathrm{ml}$ \\
\hline NA & $424 \mathrm{pg} / \mathrm{ml}$ \\
\hline DA & $44 \mathrm{pg} / \mathrm{ml}$ \\
\hline
\end{tabular}

Table 2. Diurnal rhythm of ACTH and cortisol, and dexamethasone suppression test

\begin{tabular}{lcc}
\hline & ACTH $(\mathrm{pg} / \mathrm{ml})$ & Cortisol $(\mu \mathrm{g} / \mathrm{dl})$ \\
\hline Circadian rhythm & & \\
$9 \mathrm{am}$ & 329 & 55.0 \\
$5 \mathrm{pm}$ & 241 & 44.9 \\
$9 \mathrm{pm}$ & 267 & 45.2 \\
& \\
Dexamethasone (Dex) suppression test & 63.5 \\
Dex 2 mg & 331 & 46.3 \\
Dex 8 mg & 180 & \\
\hline
\end{tabular}

Table 3. Corticotropin-releasing hormone (CRH) test

\begin{tabular}{lcccccc}
\hline & 0 & 15 & 30 & 60 & 90 & $120 \mathrm{~min}$ \\
\hline ACTH $(\mathrm{pg} / \mathrm{ml})$ & 139 & 174 & 160 & 177 & 150 & 150 \\
Cortisol $(\mu \mathrm{g} / \mathrm{dl})$ & 47.1 & 47.9 & 67.7 & 58.4 & 56.5 & 61.5 \\
\hline
\end{tabular}

were all at normal levels. Elevated cortisol and ACTH levels were not suppressed by overnight administration of $2 \mathrm{mg}$ or $8 \mathrm{mg}$ of dexamethasone (Table 2). Moreover, following the intravenous administration of 100 $\mu \mathrm{g}$ of ovine corticotropin-releasing hormone (CRH), serum cortisol and plasma ACTH levels still showed no response (Table 3). Roentgenographic examination of the skull showed a normal sella turcica. No pituitary tumor or parasellar tumor was detected by contrastenhanced computed tomography (CT) or magnetic resonance image (MRI) scan of the pituitary. High resolution $\mathrm{CT}$ of the lung revealed no abnormalities. Bronchoscopic studies were performed; however, these also gave normal results. Abdominal and pelvic CT indicated bilateral and slightly diffuse adrenal gland hyperplasia only. These findings suggested that the diagnosed Cushing's syndrome had been caused by ACTH-dependent hypercortisolism due to either pituitary or ectopic. Ten days after admission, the patient had a body temperature of $38.0^{\circ} \mathrm{C}$, blood pressure of $120 / 60 \mathrm{mmHg}$, and heart rate of $108 / \mathrm{min}$. Peripheral blood cell count revealed a white blood cell count of $1.93 \times 10^{4} / \mu \mathrm{l}$, hemoglobin of $11.2 \mathrm{~g} / \mathrm{dl}$ and a decreased platelet count of $6.2 \times 10^{4} / \mu 1$. Erythrocyte sedimentation rate was elevated. The prothrombin time was prolonged $(14.8 \mathrm{sec})$, and the activated partial thromboplastin time was also prolonged $(54.0 \mathrm{sec})$. The plasma fibrinogen content was $138 \mathrm{mg} / \mu \mathrm{l}$, and the fibrin/fibrinogen degradative products (FDP) and Ddimer levels were markedly increased to $38.1 \mu \mathrm{g} / \mathrm{ml}$ and $32.7 \mu \mathrm{g} / \mathrm{ml}$ respectively, with an anti-thrombin III 
A

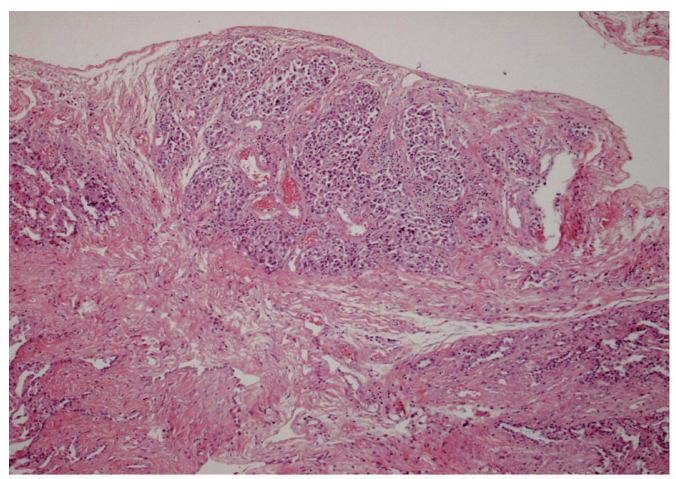

C

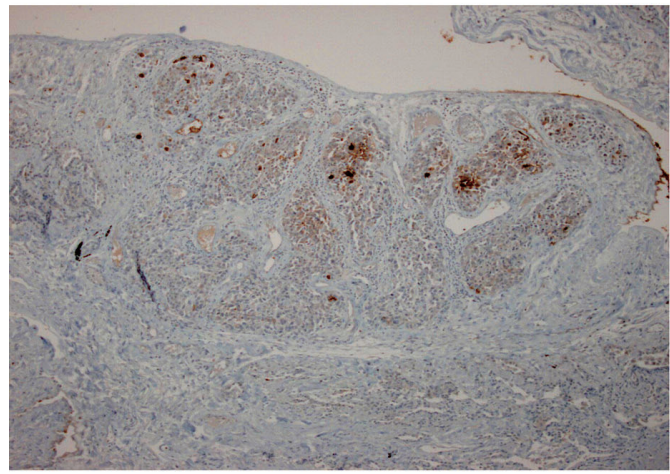

$\mathrm{E}$

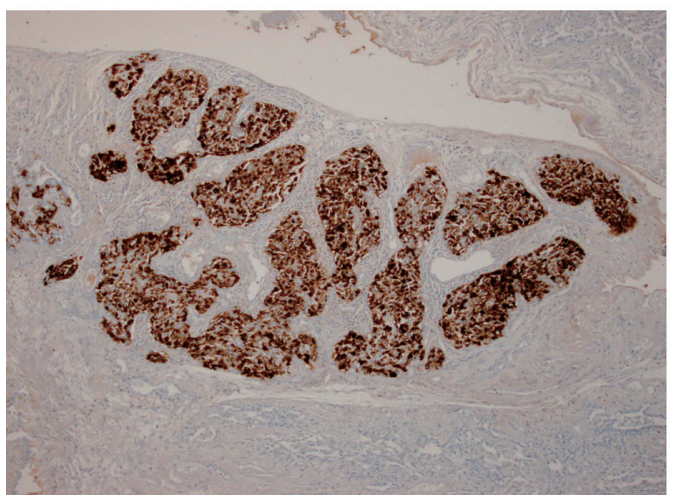

activity of $30.0 \%$. These data indicated disseminated intravascular coagulation (DIC), and we began treating the patient with antibiotics (Imipenem cilastatin $1 \mathrm{~g} /$ day) even though the culture of sputum, urine and blood showed no growth, as well as with $2000 \mathrm{mg}$ /day of gebexate mesilate and 5000 units/day of dalteparin. Despite the intensive therapy, the patient's temperature rose to $40^{\circ} \mathrm{C}$ and she became hypotensive. She was transferred to the intensive care unit, but she continued to deteriorate, displaying a worsening renal function and severe heart failure, and she also required ventilatory support. Her condition continued to worsen, and

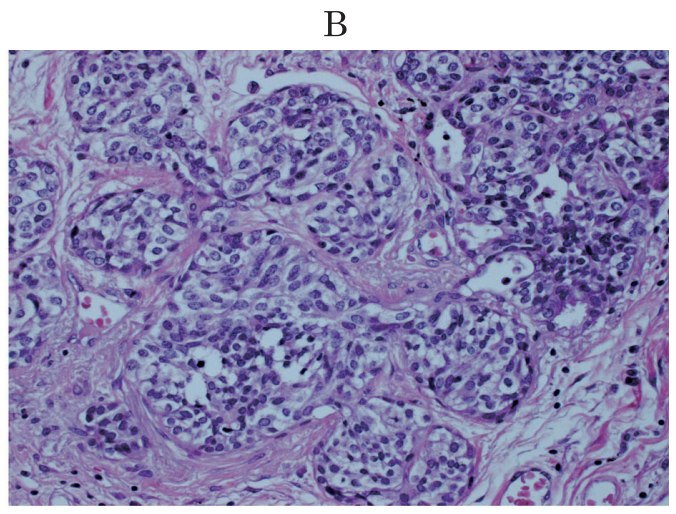

D

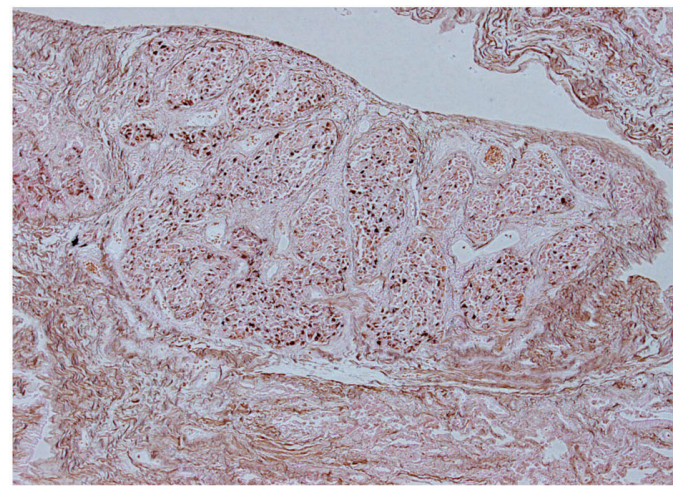

Fig. 2. Microscopically, small multiple nodules were identified at the periphery of the right middle lobe of the lung. There were multiple discrete nests of proliferating uniform oval cells. (A and B, hematoxylin and eosin) Magnification: A, $\times 20$; B, $\times 400$.

Immunostaining revealing strong positivity for corticotropin (C), chromogranin A (D) and histochemically the cells showed positive staining with the Glimelius (E) stain in the tumorlets. Magnification: $\times 20$.

she eventually succumbed to multiple organ failure 14 days after presentation in the intensive care unit.

\section{Autopsy results}

Autopsy was performed at 17 hours postmortem. Gross examination of the skull base, sella turcica, cavernous sinus, chest, and abdomen revealed no evidence of an ectopic ACTH-producing tumor. Histological examination of the pituitary gland itself and of the surrounding tissues revealed no neoplasm. The lung was removed and serially sectioned. Microscopically, 


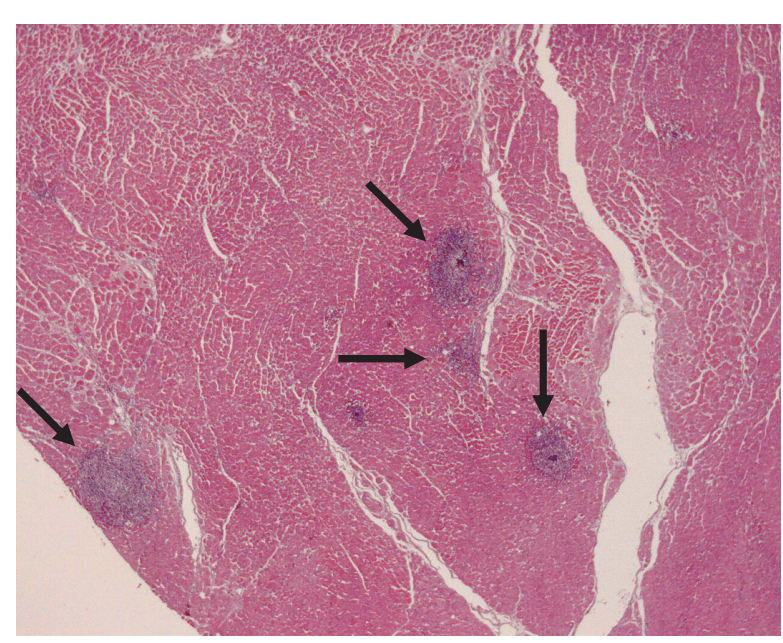

Fig. 3. Multiple microabscesses were present in the myocardium (arrows) (hematoxylin and eosin) Magnification: $\times 20$.

small multiple nodules were identified at the periphery of the right middle lobe of the lung. There were multiple discrete nests of proliferating uniform oval cells. The nests varied in size from $1 \mathrm{~mm}$ to $3 \mathrm{~mm}$ in diameter. Immunohistochemical staining (Automatic immunostaining system: Dako) of the nodules revealed scattered cells containing ACTH (polyclonal rabbit anti-human adrenocorticotropin, $1: 100$ dilution: Dako, Carpinteria, CA, USA) and many cells showed positive staining with the Grimelius and chromogranin A (rabbit anti-human chromogranin A, 1: 100 dilution: DAKO, Carpinteria, CA, USA) stain (Fig. 2). In addition, multiple microabscesses were present throughout most tissues of the body including the myocardium, lung, kidney, spleen, adrenal glands, and thyroid gland (Fig. 3). The bacterial morphology was similar in all regions and consistent with $S$. aureus.

\section{Discussion}

Recently, an increasing number of pulmonary tumorlets have been reported because of the development of radiological imaging techniques. However, clinically significant ectopic hormone production by pulmonary tumorlets is very rare. Only seven such cases of pulmonary tumorlets associated with Cushing's syndrome have ever been reported (Table 4). Sobota \& Reed [8] reported the first case of a patient with Cushing's syndrome who had a nodular infiltration of the right lung. A microscopic examination revealed the presence of multiple bronchial adenomas of different sizes, some of them consistent with a diagnosis of tumorlets. The second patient was reported by Ranchod [9], a 61-year-old woman with Cushing's syndrome, haemoptysis and a left-upper-lobe mass that proved to be a small-cell lung carcinoma with surrounding tumorlets. Immunohistochemical studies revealed positive ACTH staining in both lesions, thus suggesting that the carcinoma originated from one of the tumorlets. Rodgers-Sullivan et al. [10] reported the case of a 39-year-old patient who displayed hypokalaemia and an infiltrate in the lower lobe of the right lung. The patient underwent resection of the superior segment of the right lower lobe, and a microscopic examination revealed chronic pneumonitis with abscess formation, and the presence of numerous tumorlets. Endocrinological features were interpreted as being consistent with adrenocortical hyperplasia, and a bilateral adrenalectomy was performed. The patient died 2.5 years after undergoing an adrenalectomy and the postmortem examination revealed metastatic carcinoid tumors in the mediastinum, both lungs, mesentery, liver, spleen and kidneys. Nevertheless, the authors state that the carcinoid tumorlets were a source of excessive production of ACTH. Arioglu et al. [11] reported the case of a 9-year-old girl who presented with weight gain, growth arrest and hypertension. The endocrinological findings were consistent with Cushing's syndrome, but the results from MRI of the pituitary were normal. Nine years after a bilateral adrenalectomy, she presented with increased pigmentation, and a CT scan of the chest revealed multiple small nodules confined to the right lower lung lobe. The patient underwent a right lower lobectomy and a microscopic examination revealed the presence of tumorlets. Ozbey et al. [12] described a 35-year-old female patient with ectopic ACTH secretion due to multiple peripheral pulmonary cartinoid tumors and tumorlets. The results of a highdose dexamethasone suppression test led to the diagnosis of Cushing's disease; however, no tumor was identified on sella imaging, and bilateral inferior petrosal sinus sampling was non-diagnostic. CT of the lungs revealed multiple acinar-nodular parenchymal infiltrations confined to the left lung. They decided to explore these nodules with an open lung biopsy. The histopathological diagnosis was multiple peripheral cartinoid tumors and tumorlets of a carinoid type showing positive immunostaining for ACTH. Povedano et al. [13] reported a patient with an aggressive case of 


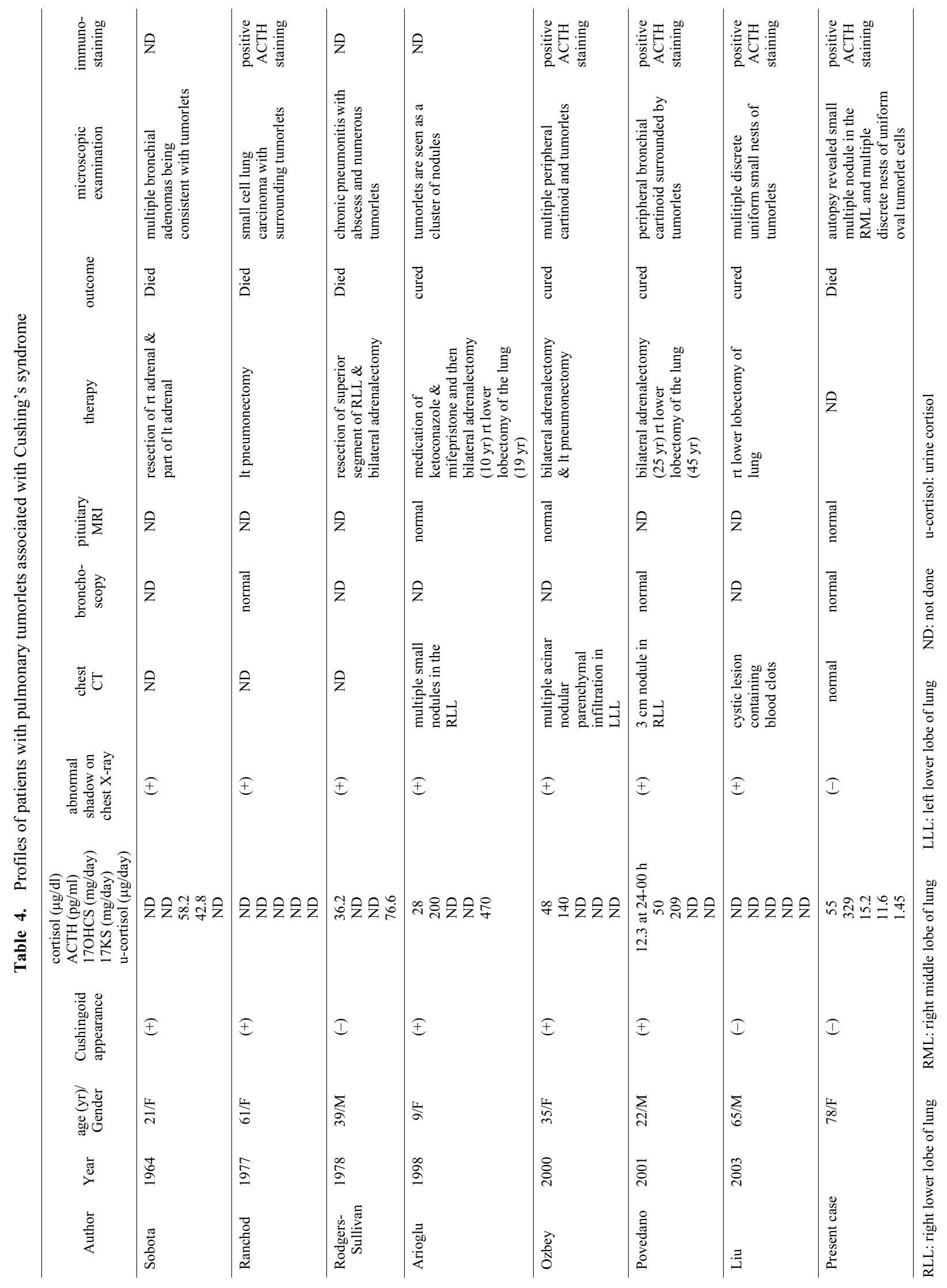


Cushing's syndrome that required a bilateral adrenalectomy, diagnosed 22 years before a 3 -cm lung nodule became apparent in a chest X-ray. The biopsy after lung surgery revealed a typical peripheral bronchial carcinoid tumor surrounded by tumorlets. Both the tumorlets and the carcinoid tumor showed strongly positive ACTH immunostaining. Recently, Liu et al. [14] reported the case of a 65 -year-old male who underwent a right lower lobe lobectomy because of a sudden attack of coughing and hemoptysis. A histological examination revealed multiple, discrete and small uniform nests of tumor cells surrounding the dilated bronchioles. Using immunohistochemistry, the proliferating cells were confirmed to be neuroendocrine in origin with ectopic ACTH production; however, there were no signs or symptoms of Cushing's syndrome. To our knowledge, the patient in our case is the first proven to have pulmonary ectopic ACTH-producing tumorlets, but the ectopic source of the excess corticotropin could not be identified until the autopsy revealed the pulmonary tumorlets that produced the excess corticotropin.

Pulmonary tumorlets, like bronchial carcinoid tumors, arise from Kulchitsky's cells and are immunoreactive to general neuroendocrine markers such as chromogranin A, synaptophysin, and neuron-specific enolase [9]. However, since there are no definite histological criteria, it is difficult to distinguish pulmonary tumorlets from carcinoid tumors. Therefore, the tumor size is arbitrarily used as a diagnostic criterion to distinguish between pulmonary tumorlets and carcinoid tumors. Since the size of most pulmonary tumorlets is less than 3-4 mm even at their largest dimension, a size of less than $5 \mathrm{~mm}$ is thus suggested as a guideline to distinguish pulmonary tumorlets from carcinoid tumors [7]. Other morphological features of pulmonary tumorlets include multiple lesions and peripheral location [15]. In this case, small multiple nodules were identified at the periphery of the right middle lobe of the lung and there were multiple discrete nests varying in size from $1 \mathrm{~mm}$ to $3 \mathrm{~mm}$ in diameter of proliferating uniform oval cells. Immunohistochemical staining of the tumorlets revealed scattered cells containing ACTH and many cells containing chromogranin A and Grimelius, confirming their neuroendocrine origin. These findings were consistent with the characteristics of pulmonary tumorlets and the tumorlets produced ectopic ACTH.

The exact incidence of tumorlets is not known, but in one study they were found at autopsy in 2 of 1900 patients with no lung disease and 22 of 2400 lung specimens surgically removed for various causes [16]. Therefore, pulmonary tumorlets should be considered in the differential diagnosis of Cushing's syndrome, especially in patients without any apparent nonendocrine tumors. Periodic CT or MRI is necessary to detect small, slow growing lesions such as pulmonary tumorlets.

When the source of endogenous Cushing's syndrome cannot be surgically removed, medical treatment, including glucocorticoid receptor antagonists and other agents is often required, because severe hypercortisolism is associated with life-threatening infection, diabetes and a high surgical mortality and the medical therapy can inhibit steroidogenesis and potentially reduce the risk of complication from hypercortisolism. The administration of the above treatment regimen should thus be considered before performing an adrenalectomy for severe, uncontrollable Cushing's syndrome to improve tissue healing $[17,18]$. In this case, the patient who had a 10-year history of type 2 diabetes mellitus displayed a high body temperature 10 days after admission, and the data indicated DIC. We assumed that an acute onset of severe infection and continuous DIC was a possible diagnosis in this patient, even though the culture of sputum, urine and blood showed no growth in spite of the multiple microabscesses which were present throughout most tissues of the body including the myocardium, lung, kidney, spleen, adrenal glands and thyroid gland on the autopsy results. We should have recognized that she was a compromised host and we therefore should have started the medical therapy for hypercortisolism at once, and then investigated the location of the ectopic ACTH producing tumor. Regarding the optimal treatment of this case, based on the above findings, priority should have instead been given to the treatment instead of the diagnosis.

In conclusion, this case demonstrates that pulmonary tumorlets should be considered in the differential diagnosis of Cushing's syndrome or a high serum cortisol level, and in particular in patients without any apparent non-endocrine tumors, who must be treated immediately with medical therapy to inhibit steroidogenesis in order to reduce the risk of complications from hypercortisolism. 


\section{References}

1. Solcia E, Kloppel G, Sobin LH (2000) WHO Histological typing of endocrine tumors. 2nd edn. Berlin, Springer: 72-74.

2. Wajchenberg BL, Mendonca BB, Liberman B, Albergaria Pereira MA, Carneiro PC, Wakamatsu A, Kirschner MA (1994) Ectopic adrenocorticotropic syndrome. Endocr Rev 15: 752-787.

3. Imura H, Nakai Y, Nakao K, Oki S, Matsukura S, Hirata Y, Fukase M, Hattori M, Yosimi H, Sueoka S (1978) Functioning tumors with special reference to ectopic hormone producing tumors. Protein Nucleic Acid Enzyme 23: 641-656 (In Japanese).

4. Shibusawa N, Mori M (2004) Etiology of ectopic hormone producing tumors. Nippon Rinsho 62: 865-870 (In Japanese).

5. Armas OA, White DA, Erlandson RA, Rosai J (1995) Diffuse idiopathic pulmonary neuroendocrine cell proliferation presenting as interstitial lung disease. $\mathrm{Am} \mathrm{J}$ Surg PathoI 19: 963-970.

6. Rešl M, Kohout A, Novotný J, Mědílek K (2001) Pulmonary carcinoid tumorlet: a neoplastic affection? Ćes-slov Patol 37: 182-184.

7. Travis WD, Colby TV, Corrin B (1999) WHO histological typing of lung and pleural tumors. 3rd edn. Berlin, Springer: 61-66.

8. Sobota JT, Reed RJ (1964) Multiple bronchial adenomas, Cushing's syndrome and hypokalemic alkalosis. Report of a case. Dis Chest 46: 367-371.

9. Ranchod M (1977) The histogenesis and development of pulmonary tumorlets. Cancer 39: 1135-1145.

10. Rodgers-Sullivan RF, Weiland LH, Palumbo PJ,
Hepper NG (1978) Pulmonary tumorlets associated with Cushing's syndrome. Am Rev Respir Dis 117: 799-805.

11. Arioglu E, Doppman J, Gomes M, Kleiner D, Mauro D, Barlow C, Papanicolaou DA (1998) Cushing's syndrome caused by corticotropin secretion by pulmonary tumorlets. N Engl J Med 339: 883-886.

12. Ozbey N, Bozbora A, Kalayci G, Kapran Y, Yilmazbayhan D, Dizdaroglu F, Orhan E, Sencer E, Molvalilar S (2000) Cushing's syndrome caused by ectopic corticotropin secretion by multiple peripheral pulmonary carcinoids and tumorlets of carcinoid type. J Endocrinol Invest 23: 536-541.

13. Povedano ST, Pastor CV, Seoane CP, Reina LJ, Moreno MA, Ortega RP, López-Rubio F, López PB (2001) Ectopic ACTH syndrome caused by pulmonary carcinoid tumourlets. Clin Endocrinol (Oxf) 54: 839842 .

14. Liu SM, Wu HH, Wu CJ, Chien LK, Lein RM (2003) Adrenocorticotropin-producing pulmonary tumorlets with lymph node metastasis. Pathol International 53: 883-886.

15. Colby TV, Wistuba II, Gazdar A (1998) Precursors to pulmonary neoplasia. Adv Anat Pathl 5: 205-215.

16. Whitwell F (1955) Tumourlets of the lung. J Pathol Bacteriol 70: 529-541.

17. Sonino N, Boscaro M, Fallo F (2005) Pharmacologic management of Cushing syndrome: new targets for therapy. Treat Endocrinol 4: 87-94.

18. Nieman LK, Ilias I (2005) Evaluation and treatment of Cushing's syndrome. Am J Med 118: 1340-1346. 